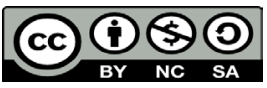

\title{
Argullol, R. (2014). Pasión del dios que quiso ser hombre. Barcelona: Acantilado. ISBN: 978-84-16011-10-0. Número de páginas: 88.
}

doi:10.11144/Javeriana.uph31-63.rpdh

COMO Un FÁmUlo QUE ACOMPAÑA EN SILENCIO -y con gran admiración- el caminar de treinta y tres años de la existencia de un monstruo que tuvo la osadía de querer ser hombre y sentir en su totalidad la pasión de lo humano, es la travesía a la que nos conduce el escritor y filósofo barcelonés Rafael Argullol Murgadas en este pequeño libro dividido en tres secciones: un Relato, una Confesión y 23 láminas a todo color donde Da Vinci, Miguel Ángel, Velázquez, Botticelli, Rafael, entre otros, representan la crudeza de un ser que se retó a sí mismo para llevar a cabo un plan. Cada palabra escrita por Argullol es como el trazo fino y delicado de un pintor que dibuja a través de su pincel los movimientos corpóreos de un dios metido en la piel de un hombre, de un dios que se dejó vencer por la curiosidad del carnaval grotesco de lo humano, de un dios que dijo haber amado en extremo para cometer un suicidio divino haciéndolo pasar como un asesinato humano ( $p$. 26) ${ }^{1}$. Todo estaba minuciosamente planeado por este héroe de la soledad que se abalanzó con fuerza al sufrimiento, sin importar las consecuencias que traería su febril decisión: ser como un mortal, no obstante pensar como un dios.

Pasión del dios que quiso ser hombre no es el relato de un creyente o de un erudito engreído que pretende tener la última palabra sobre la vida y muerte de Cristo - ¿Habrá acaso alguna verdad última?-, sino que es el relato de un inquieto por la figura de Cristo, de un hombre apasionado artísticamente por el cuerpo de otro hombre que a todas luces sigue generando un impacto profundo en la mente de sus estudiosos y sus seguidores, en definitiva, de un

\footnotetext{
${ }^{1}$ Este dios se escribe con minúscula, pues el mismo Argullol indica en una entrevista realizada por rtve que al redactar este libro se sitúa fuera del dogma cristiano, de tal manera que este dios puede ser equiparable al de cualquier otra religión o mito. Además, en su libro sostiene que "[n]uestra relación con lo sagrado es demasiado profunda como para ser entregada al abrazo de una religión" (p. 45). La entrevista completa en: http://www. rtve.es/alacarta/videos/para-todos-la-2/para-todos-2-entrevista-rafael-argullol-filosofoescritor/2627539/
} 
hombre que ha estado acompañado desde sus primeros años por la imagen de la encarnación de nuestra propia naturaleza humana, de nuestros límites, de nuestras ambiciones ${ }^{2}$. Los mayores cómplices que tiene Argullol son los artistas, pues la mentira que cuentan estos en sus pinturas permite recrear los episodios de una experiencia atravesada por la mascarada humana; además, la unión de todos esos esfuerzos pictóricos podrá ayudar a alumbrar alguna verdad -quizá la misma que vino a anunciar con demasiado entusiasmo aquel monstruo-.

La aproximación a la Pasión de Jesús de Nazaret vista a la luz de un relato, como si de su mejor biógrafo se tratara, y una confesión, hacen que la brevedad de este libro sea considerada como "gotas de quintaescencia" que acercan al lector a una naturaleza dual que vivió toda su vida en una tensión dolorosa, arrastrando hasta el extremo a su madre y a los que lo acompañaron en su peregrinaje de difusión de la revelación que le fue dada en el desierto de Judea, donde estuvo cuarenta días y cuarenta noches tentado por el demonio: ¡la Resurrección de la carne!. Luego de este momento decisivo, le restan tres años para completar el plan que se había trazado desde antes de llegar al vientre de aquella joven pueblerina, pues el mayor monstruo que conocemos tuvo la osadía de ser autor y protagonista de su propia historia, y de llevar al extremo su deseo intenso de romper las fronteras entre el cielo y la tierra.

Podría decirse que Argullol se adentra en la mente de Cristo para mostrarles a quienes se acercan a estas páginas el aprendizaje-sufrimiento por el que pasó este dios con ansias de mortalidad, con anhelos de conocimiento de los placeres de la carne. Argullol no se detiene en todos los detalles que se podrían desprender de los evangelios o de las representaciones de los artistas que él trae intencionalmente para apoyar su corta pero esencial narración de una especie de tableau vivant de aquellos instantes apasionantes y contradictorios del periplo emprendido por Cristo, en su locura de llevar un

\footnotetext{
${ }^{2}$ En el momento de la Confesión nos encontramos frente a frente con la metamorfosis que ha sufrido el espíritu de Rafael Argullol en el recorrido por una religión de la cual se declara no cristiano - porque no afirma ser no creyente y mucho menos carente de fe, pues de alguna manera la educación impartida lo acercó poco a poco a los enigmas del cristianismo, interesándolo, más no emocionándolo-, pero sí un apasionado por la figura de Cristo y por ciertos detalles que acompañan al cristianismo. Parecieran mociones internas contradictorias, no obstante, la tensión se intenta resolver a través de la luz que brinda el arte y su manera de trabajar con la naturaleza viva, no con ideas (p. 49).
} 
testimonio "de la verdad" hasta el punto de sacrificarse en la cruz por ella, sin ningún tipo de salvación, pues no se quiere ni se puede salvar el mayor solitario de todos los seres en la tierra, el mayor taumaturgo de todos los tiempos.

Ni los sacerdotes ni los teólogos han estado en condiciones de comprender esta suerte de mística invertida por la que un dios se precipita dolorosa y jovialmente hacia lo humano. Por eso cuando dejo de lado las doctrinas cegadoras para intentar vislumbrar qué luz no se había extinguido para mí en la historia de Cristo recurro a los artistas. Los artistas han captado la carne del sacrificio de un modo que las palabras, por mucho que se transmitieran con exactitud, no podían hacerlo. (p. 55)

De ahí que sean los pintores los encargados de recoger el legado de esta condición híbrida e incomprensible, pues el escenario elegido para dar rienda suelta a una curiosidad les fascina intensamente y los pone en marcha para intentar no dejar algún cabo suelto en la Pasión de un dios que sintió la intimidad de la carne. Sus lápices, pinceles, paletas de colores, estuvieron presentes desde antes de los últimos momentos de la extinción en la cruz, exponiendo el rostro de María cuando le anuncian que será la madre de un dios-hombre, retratando la seriedad de José que no logra entender nada de lo que sucede a su alrededor, dibujando algo de los treinta años de Cristo que se consumieron en la mediocridad humana. Trascurridas esas tres primeras décadas, los pintores siguen a Cristo a todas partes pues solo falta poco para que todo quede consumado; así que se ponen a marchar a su lado dejando consigna de los milagros realizados (Giotto di Bondone), del momento dramático del anuncio de la traición (Leonardo da Vinci), del encuentro a solas con Poncio Pilato (Nikolai Ge), de la flagelación (Piero della Francesca), de la crucifixión (Diego Velázquez, Miguel Ángel), del descenso de la cruz (Sandro Botticelli, Rogier van der Weyden), en definitiva, del sacrificio y del dolor que es voluntariamente aceptado por este héroe solitario.

La atracción que ejerce Rafael Argullol con este texto es tal que envuelve a aquellos lectores filósofos, artistas, historiadores del arte, teólogos, interesados por la figura central en la historia del arte europeo -Cristo- y los enfrenta con la encarnación, con aquel que aprendió a ser carne, a tener sentidos, a ser hombre. Desde el mismo título y la imagen que ilustra la carátula, su libro es provocador e invita a sumergirse en las pocas páginas que recogen una historia convulsionada por un amor desbordado hacia la 
humanidad; el aire poético y artístico al que recurre Argullol le ayuda a deslizar suavemente su pluma por los momentos de fatalidad y grandeza de una naturaleza humana muy particular, una naturaleza que sedujo a los artistas a lo largo de la historia y que fue seguida con celo incluso hasta después de su muerte.

Anna Valentina Beltrán Sánchez valentinabeltran10@gmail.com 